\title{
THE GERMAN SOCIAL DEMOCRATIC PARTY AFTER WORLD WAR II: THE CONSERVATISM OF POWER
}

\author{
H. Kent Sahellenger, Jr. \\ University of Oklahoma
}

$\mathrm{O}$ N NOVEMBER 15, 1959, an extraordinary conference of the German Social Democratic party adopted a new program, one which departed abruptly from socialist tradition. One year later, on November 25, 1960, the party conference in regular session applauded the party's new "team," a group of personable candidates headed by Willy Brandt. In the fall of 1961, this team, with Brandt as chancellor candidate, led the party in a campaign using the most modern techniques, many copied frankly from the American presidential campaign of the previous year. This three-fold change of program, leadership, and style was unlike any other in the party's history. It was the culmination of a conscious effort to adapt to changing times, an effort, in short, to modernize socialism.

Despite considerable American interest in the German working-class movement, dating at least from Robert Michels' classic Political Parties, and the more recent concern with the "end of ideology" which the above changes are supposed to represent, little has been written about how these changes occurred, i.e., the way in which the changes were initiated, elaborated, and carried to completion. ${ }^{1}$ This article undertakes that task with regard to the most significant aspect of the SPD's postwar development: the evolution of the new party program. Its thesis is that the program was the work not of rebellious Young Turks but of the established leadership, men of the type believed by Michels to be necessarily opposed to change. The article attempts to show that Michels' rule that "power is always conservative" 2 can properly be understood only by relating his work to that of contemporary political sociologists, especially those who have explored the bases of the "end of ideology."

\section{Ideological Development After World War II}

The history of the international labor movement furnishes innumerable examples of the manner in which the party becomes increasingly inert as the strength of its organization grows; it loses its revolutionary impetus, becomes sluggish, not in respect of action alone, but also in the sphere of thought. More and more tenaciously does the party cling to what it calls the "ancient and glorious tactics," the tactics which have led to a continued increase in membership. More and more invincible becomes its aversion to all aggressive action."

It is of course true that the SPD has lost its "revolutionary impetus." Since World War II, however, it has proved "sluggish" in neither action nor thought.

\footnotetext{
${ }^{1}$ See Douglas A. Chalmers, The Social Democratic Party of Germany (New Haven: Yale U. Press, 1964), the works cited there. Chalmers' excellent study relates the party's changing structure to its changing function; its approach is primarily theoretical rather than historical. Several interesting aspects of the SPD's postwar development remain to be explored, e.g., the focus of the present article: the role of the leadership in the program reform. The article is based on research in the party archives and personal interviews during and following the national election of 1961.

2 Robert Michels, Political Parties, trans. Eden and Cedar Paul (New York: Collier Books, 1962), p. 333.

${ }^{3}$ Ibid, p. 337 .
} 
Nothing is more apparent than the departure from "ancient and glorious tactics." Two possible explanations occur. Either that departure was caused by the arrival in power of a new and different kind of socialist leader, or the established leaders, reacting to stimuli unknown to Michels, set the party on its new course. The answer requires a brief review of the party's renaissance in the early postwar years.

Inside Germany, at least, party activity virtually ceased during the Nazi regime. When the nightmare was over, surviving socialists met to re-establish their party. Kurt Schumacher was accepted as the SPD's new leader. Thanks to the power of his position and the force of his personality, his political views established the ideological and organizational direction of the party in the postwar period. Those views were set down within weeks after Germany's surrender. His analysis of the causes of Germany's ruin was based squarely on the Marxist concepts of class, class conflict, and the state as an instrument of the ruling class. He made it clear that he continued to perceive German politics in terms of class, i.e., those with and those without property, represented by the "bourgeois" parties and the SPD respectively. Warning of an attempt by the shattered ruling class to re-establish its control, Schumacher demanded a "new Germany." To this end, extensive nationalization would be required. Justification for this was found not so much in socialist doctrine as in Germany's immediate predicament - the state of the German economy and the need to prevent undemocratic elements from regaining economic and political power. (Similar demands, for similar reasons, were included in the Christian Democrats' Ahlen Program of 1947.) Perhaps most important, socialization was described as a means toward the true socialist goals, not as an end in itself.

Schumacher made it clear that he had resolved the old controversy - workers' party or people's party - in favor of the latter: "Socialism is no longer the affair of the working class in the old sense of the word. It is the program for workers, farmers, artisans, tradesmen, and the intellectual professions...." 4 The same eclecticism was applied to party ideology: "It is no matter whether someone becomes a Social Democrat through the methods of Marxist analysis, for philosophical or ethical reasons, or out of the spirit of the Sermon on the Mount."

Schumacher's conception of Marxism was central to his political thought: "As Social Democrats we have no cause at all to damn Marxism generally and to throw it overboard. If Marx is not a catechism for us, it is the method, especially used in analysis, to which we owe more strength and more perceptions and more weapons than every other scientific and sociological method in the world." 5 With regard to the crucial categories "class" and "class conflict," Schumacher wrote: "The class struggle is not obsolete - certainly not - but it is an important element of the specific Marxist theory of the state, and as such is conceptually limited. . . The Social Democratic Party should have the courage to eliminate the expression 'class struggle'. ..." Finally, Schumacher took special pains to distinguish social

\footnotetext{
- See Arno Scholz, Turmwächter der Demokratie, Vol. II : Reden und Schriften (Berlin: Irani Verlag, 1952). The above is paraphrased or translated from Schumacher's speeches in Scholz, pp. 33-44.

Ibid., p. 337.

${ }^{6}$ Ibid., p. 297.
} 
democracy from communism, even before it became politically necessary to do so. He accused the communists of corrupting Marx, denying that Social Democrats shared with them either means or ends.

Implicit or explicit in the above are ideas which made possible the development of the SPD's new program. First, Schumacher considered Marxism a method and guide, not a collection of universal and eternal verities, and only one of several acceptable roads to democratic socialism. Second, he believed it necessary to appeal beyond the working class. Third, he realized the importance of making a clear distinction between the methods and goals of democratic socialism. Fourth, his thinking was primarily pragmatic, not dogmatic.

The results of all this can be stated concisely. Schumacher's views on Marxism allowed the participation of other pragmatic Marxists and professed non-Marxists in the development of the party's ideology, with the inevitable consequence of diluting the Marxist content of the ideology. His emphasis on a broader appeal permitted modification of the party's electoral strategy and tactics, a change which inspired further ideological reform. His anticommunism and pragmatism encouraged increasing emphasis on "free" aspects of the party's program: e.g., the promotion of "genuine" economic competition. For the same reasons, and because of his careful distinction between the means and the ends of socialism, nationalization and planning could gradually be de-emphasized as conditions, and the party's experts' interpretation of conditions, changed.

The SPD's ideological evolution after 1952 may have exceeded Kurt Schumacher's intentions; it may have gone farther than if he had remained at the helm. It is clear, however, that his thinking represents the first stage of that evolution. Party conferences in 1945, 1946, and 1947 heard the Schumacher views expounded by him and by official leadership spokesmen and approved them with little dissent. At the 1948 conference, the economic Referent made the clearest statement to that time of the nature of the changes already under way. He began by acknowledging that the party had no clear picture of the new society which it was proposing, and then commented:

When our functionaries talk of our future, in meetings around the country, they do so all too often in the style and with the weapons of the Erfurt Program of 1891. They talk according to obsolete stereotypes about the socialization of the means of production, of a totally planned economy and thereby offer only a diluted version of the communist recipe. The masses, however, feel that such agitation is no longer appropriate, that theory and practice are no longer in accord; and many leave such meetings dissatisfied, unenlightened and full of doubt. That which was still revolutionary and appeared to be a very distant goal, 57 years ago when the Erfurt Program was published, has today become reality, thanks to the untiring effort and power of our party. The task is, then, to formulate new tasks and to set new goals.... ${ }^{\top}$

This was a frank admission that in the opinion of the leadership the party's goals, the means to achieve them, and the style in which those ideals were presented to the public were in need of modernization. The statement implicitly recognized that opposition to change might come from the lower ranks of the party bureaucracy.

'Protokoll der Verhandlungen des Parteitages der Sozialdemokratischen Partei Deutchlands, 1948, p. 139. (Minutes of the party conference, hereafter cited as Protokoll, with date.) 
But the leadership was committed to change, nevertheless, and was resolved to overcome any resistance.

The 1948 conference authorized the leadership to create a program commission - demands for the drafting of a new basic program had previously been rejected because of the need to concentrate on current problems — but after the SPD's defeat in the 1949 Bundestag election, efforts were concentrated on the development of a concise "work program" for use in the next campaign. In 1952, the Aktionsprogramm was presented to the conference and approved. The document was entirely consistent with Schumacher's views. Significant shifts in emphasis were apparent, however. The list of industries to be socialized was considerably shorter; the demand for planning was no longer as urgent as in the first postwar statements.

Kurt Schumacher died in 1952 - two wars had left him maimed and weakened - but his successor, Erich Ollenhauer, made no attempt to turn the party from the course that Schumacher had charted. In early 1953 two meetings of party functionaries were called for the purpose of explaining the economic aspects of the Aktionsprogramm. Their effect was to move the official ideology even farther along the lines already established. The tenor of the first meeting is indicated by the slogan introduced there (and eventually incorporated into the basic program): "Competition insofar as possible, planning insofar as necessary." The second meeting focused on the importance of appealing to the middle class. Even after the SPD's first real setback, the electoral defeat of September 1953, the trend continued.

In 1955 a commission was at last appointed to begin work on a new basic program. A draft was completed and offered for the consideration of the 1958 party conference which met in Stuttgart. The draft was duly approved with no important change and the executive was authorized to call an extraordinary conference for formal adoption of the program. The call was forthcoming; in May, 1959, SPD delegates assembled in Bad Godesberg, near Bonn.

The Godesberg Program opens with a short statement of the "contradiction of our time," i.e., that man has unleashed the atom but fears its consequences; that productive capacity has reached a new high, but distribution is still unjust; that space is being conquered but the earth remains divided. Democratic socialism offers a "new and better order." 8 This introduction represents the most startling departure from previous practice: the abandonment of the traditional Marxist analysis of economic, social, and political conditions. That custom had been maintained as late as the Stuttgart draft. However, its elimination is neither surprising, in view of postwar trends, nor incompatible with Schumacher's early pronouncements on Marxist doctrine. Continuing, the Program defines social democracy as a "community of people who come from various schools of belief and thinking." (Marxism is not one of the schools mentioned.) Economic goals are a "continuously growing prosperity and a just participation of all in the product of the economy, a life in freedom without unworthy dependence and without exploitation." Governmental responsibility for maintaining a prosperous economy is assumed but the state "should restrict itself essentially to methods of indirect influencing of the economy." Planning is virtually a last resort: "Free consumer choice and free choice of employment are decisive

${ }^{8}$ The Godesberg Program may be found in Protokoll, 1959. 
principles; free competition and free enterprise initiative are important elements of social democratic economic policy. ... Competition insofar as possible, planning insofar as necessary." Concentrations of economic power are to be avoided by regulation, publicity, and, again as a last resort, socialization: "[Public enterprises] become a necessity where, for natural or technical reasons, activities vital to the community can be conducted in an economically feasible way only with the exclusion of competition."

In short, the Godesberg Program adheres to and confirms the trends apparent since Kurt Schumacher's first postwar statements. This was not, of course, coincidence. The established party leadership - Schumacher, his subordinates, and their successors - controlled the program development at every step of the way.

\section{The Role of the Leadership in Ideological Development}

It has been noted that the party conferences of 1945, 1946, and 1947 accepted the leadership's policies with little dissent. (Although one delegate remarked in 1946, "I can not avoid the impression that many of our comrades hid Marx's Das Kapital and the socialist literature so well that so far it hasn't been found again.") ${ }^{9}$ At the 1948 conference the first step was taken toward a new basic program. The party executive presented the following proposal to the delegates: "The party conference authorizes the party executive to establish a program commission immediately. The program commission's draft for a party program is to be distributed to the whole party for discussion before it is submitted to the party conference for a vote." 10 The effect of this was to place the composition of the program commission squarely in the hands of the executive. The delegates were aware of that; several speakers thought that the task should be given instead to the conference. The fact that this point was made by delegates who also opposed the trend of the leadership's thinking suggests that they felt that the conference was more likely to appoint a commission of their persuasion than was the executive. However, traditional loyalty to the leadership prevailed and the original proposal was approved over only eight opposition votes (of over 300 present).

Before work on a basic program was begun, however, attention was diverted to the Aktionsprogramm. At the 1952 conference an official draft was presented by a leadership spokesman, Willi Eichler, the man who was to supervise the SPD's program development to its culmination at Bad Godesberg. For the purposes of handling the many amendments proposed to the official draft, the executive nominated an editorial committee which, as usual, was duly approved. The committee consisted of seventeen men and women: seven from the executive, two of the executive's experts, and eight representatives of the party districts. Obviously, such a committee could not be expected to recommend approval of proposals which would seriously alter the official draft. This proved to be the case. The committee's draft differed in no important way from the draft originally submitted by the executive. The committee's draft was then accepted by the conference as the new Aktionsprogramm.

${ }^{9}$ Protokoll, 1946, pp. 125-26.

${ }^{10}$ Protokoll, 1948, p. 208. 
Similarly, in 1954 when amendments to that program were proposed, the official proposals were virtually guaranteed approval. Another editorial committee was created, composed of forty-seven delegates nominated by the executive. After objections that the party districts were not adequately represented, three additional members were nominated from the floor. All fifty were elected. Once more, program development remained firmly in the control of the leadership. The officially proposed amendments were approved without significant change by the committee and then by the conference over "a few" opposition votes.

Attention turned again to the need for a basic program. In 1955, a commission was formed; its thirty-four members, headed by Willi Eichler, were appointed by the executive and subsequently confirmed by the 1956 conference. As noted above, the commission's product, the draft of the basic program, was submitted to the party conference of 1958 . Suffice it to say that after vigorous, if limited, opposition, all relevant nonofficial proposals were disposed of as recommended by the leadership and the draft was approved.

The following year, at the culminating conference in Bad Godesberg, the usual procedure was followed. The executive's draft was the basis of discussion; all proposals from sources other than the leadership were screened by the leadership; its recommendations for disposal of these proposals were made known to the conference and a vote was taken on each. Those which were not summarily rejected were referred to an editorial committee nominated by the leadership and confirmed, pro forma, by the conference.

Of the 212 votes taken on the proposals submitted by lower party organizations, only two went contrary to the leadership's recommendations; neither was important. On the final ballot, the Godesberg Program was formally adopted over 16 (of more than 300 ) negative votes.

The leadership's privilege of nominating all drafting commissions and editorial committees was an important means of directing the program development. (In an interview, Dr. Karl Schiller, the leading economic expert, confirmed that the privilege was exercised in such a way as to insure progress in the desired direction.) However, it is clear that the party statute gives the leadership no formal means of requiring a party conference to accept its nominations or to approve its draft proposals, or of manipulating conference delegations to obtain satisfactory results. The extent of the executive's domination of the SPD's ideological evolution can fully be understood only by recalling the techniques of persuasion available to such a body.

Unable to purge doubters and opponents from the party conferences, the leadership accomplished its task of persuasion of the rank-and-file and their representatives in part through a general program of education of members and functionaries. Systematic attempts were made to reach the lower echelons of the party. A steady stream of articles by the party's experts appeared in the SPD newspaper and journal. Discussion material was sent to local organizations and speakers were supplied on request. In addition, functionaries' meetings were called for the purpose of making known the leadership's views, with little or no rebuttal permitted.

Besides these educational efforts, the leadership made full use of the natural advantages which accrue to the executive of any large organization - precisely the 
advantages described by Robert Michels. The executive is a small body whose nucleus comprises experienced, full-time leaders whose own knowledge is buttressed by the experts at their command. This nucleus is required and able to make decisions and pronouncements in reaction to daily events, many of which cormmit the party irrevocably, in that they are politically or practically impossible to undo. This experience, expertise, and capacity to present faits accomplis is augmented by the prestige of the leaders and by loyalty to the organization, both of which the leaders can encourage in a variety of ways. The membership of the organization is in a comparatively weak position. Relatively apathetic and uninformed, it is represented in party decisions only by delegates indirectly elected to the national conference. Nominally sovereign, the conference is a body of almost 400 which meets three days every other year, with all the limitations which that implies. Even though the delegates are for the most part functionaries in their own right, they too are subject to leadership influence.

At every party conference the leadership enjoys distinct advantages. The party chairman opens the gathering with a long address which sets the tone, defines the problems, and suggests the proper answers. Business proceeds according to an agenda drafted by the leadership. Topics are introduced by a respected, experienced, and knowledgeable representative of the leadership who explains the official position on matters before the conference. The leadership's comments and recommendations on non-official proposals are made known. At any point in the subsequent discussion, the leadership's best speakers may be sent up to counter arguments from the floor.

While all proposals to conferences are ordinarily published several weeks in advance to allow preparation of alternatives, sometimes charges of "railroading" are heard. In 1954, for example, a delegate complained that the executive had presented forty-one proposals for amending the Aktionsprogramm, some of which involved important substantive change, and had demanded that they be adopted after only three days' consideration. (His complaint was overridden by an 'overwhelming majority.") However, such tactics are seldom necessary. The intangible powers already described are more than enough to insure near-unanimous support of the leadership's position on practically every issue. Near-unanimity does not mean that all are convinced. In the case of the party program, it would be a mistake to assume that the leadership had genuinely persuaded all those who supported the leadership with their votes. Many no doubt cast their votes with misgivings. The votes counted, nevertheless. Sincere or not, they constituted uninterrupted acceptance of the process which culminated in the Godesberg Program.

\section{The Leadership: Personnei}

The fact that the SPD's ideological development after 1945 was at all times firmly under the control of the leadership becomes significant when the composition of the leadership is examined.

At the party conference of 1947, the paid, full-time nucleus of the executive was established for the first postwar period. With one deletion, this seven-man body presided over the initial phase of the program development, the preparation of the 
Aktionsprogramm. Schumacher was the oldest at 51 ; five of the seven were in their middle 40's; the youngest was $33 .{ }^{11}$ Schumacher alone had held public office. Only Ollenhauer had been a member of the executive chosen in 1933. (One had been co-opted into the exile executive during the war.) But all had held paid party offices before the war.

Just as the professional leadership comprised experienced party functionaries, so did the executive as a whole. Biographical data are available for twenty-three of the twenty-five elected in 1947. Of these, the average age was 50 . Records of thirteen show prewar experience as functionaries. (Given the omissions revealed by crosschecking, it is likely that more had such experience.) Four show both party and public office. Three more had apparently served exclusively in public office. (While about one-fourth of the unpaid executive was replaced at each party conference, no significant changes in either age or previous party experience took place.)

Granting the imperfection of the data, it is apparent that the professional nucleus of the party leadership and the entire executive in office when the party's postwar policies were set down in the Aktionsprogramm were composed not of newcomers, but of members of the "middle generation," all veteran party members, most of whom had had years of service as party organizational functionaries.

At the 1952 conference, the first after Schumacher's death, Ollenhauer was raised to the chairmanship, the youngest of the members was released for other work, and two were added to the executive. The new members were 48 and 56 years of age, both with organizational and public office experience. This nucleus, which did not significantly differ from its predecessor, remained in power without change until 1958. Turning again to the executive as a whole, no change was apparent in the executive which was to preside over preparation of the first draft of the basic program. The average age was 53. Records of three, all paid members, show experience in organizational positions only. Eighteen had held both organizational and public positions. Records of nine show public office only. (Again, it is likely that the extent of organizational background was even greater than these figures indicate; also, some listed as holding both types of positions were actually much more identified with the party organization, e.g., Ollenhauer.) Thus, there was still no significant infiltration of the executive by a new element to which the progressive reformation of the party program could be attributed.

While the executive, in particular the paid, full-time nucleus, presided over the drafting process which culminated in the Godesberg Program - at least in the sense that the process could not have continued in the established direction without the general approval of the executive - the executive itself was not the actual drafting agent. A variety of standing and ad hoc bodies contributed to that process; e.g., the permanent specialized committees attached to the executive, editorial committees established at party conferences, and the like. Personal data on all those concerned with the program are not available, and analysis would be inconclusive at best; there would be, for example, no way of distinguishing nominal participants from those

\footnotetext{
${ }^{11}$ Biographical data are taken from the party archives, Wer ist Wer, and the Bundestag handbook. In every case, data were originally supplied by the individuals concerned. This of course raises the problems of omissions and lack of uniformity. Therefore only the most basic and generally available factors are considered.
} 
who substantially influenced the end result. Study of the program commission established by the executive in 1955 for the creation of the Godesberg Program is instructive, however, in that, according to Willi Eichler, "the greatest part of the participants in the preparatory work are members of this commission." 12

Data are available for twenty-nine of the thirty-two on the commission. Average age at the time of appointment was slightly over 48 , about the same as the executive. The educational level, however, was much higher. Only two of the eleven members of the paid executive to 1958 had had university education, and only fourteen of the forty-four members of the unpaid executive. Seven of those held doctorates. On the program commission, on the other hand, twenty-two of the twenty-nine studied had had university training and twenty of those held doctorates. In terms of primary adult occupation, none of those on the paid executive and only three of the unpaid executive were active in academic or research vocations. On the program commission, the largest single group, eleven of the twenty-nine, were professors or researchers of some kind. Emphasis on academics, however, did not mean that the work of program development was left to strangers to the party. Of the twenty-nine, nineteen had held public office, and all but six had been active in the organization as well.

It has been shown that the postwar ideological development of the SPD was initiated by Kurt Schumacher and watched over by his, and his successor's, executives. In addition, the available data have demonstrated that in these executives, experienced party functionaries were predominant. The actual work of development was done by appointees of the executive. While the appointees themselves were largely highly educated specialists, many of them academicians, most had had long and close association with the party. Moreover, while the advice of the experts no doubt exerted considerable influence on the decisions of the executive, their appointment and reappointment was at all times dependent on the executive.

At no point was the evolution of the Godesberg Program significantly influenced by a generation or faction new to the principles or the organization of the Social Democratic party. At no time, at least until 1958 when the program was virtually complete, was it out of the control of experienced, professional party functionaries.

\section{The Leadership: Motivations}

What caused the SPD's leaders and experts to break with the party's tradition of radical, doctrinaire programs? The writings and public statements of these Spitzenfunktionaere suggest a number of factors which weighed heavily in their thinking. One of these was the Russian revolution. Dismay at its totalitarian turn is evident in many public statements by the postwar leadership. At the first postwar conference, in 1946, Willi Eichler said: "For dozens of years we thought we knew that the injustice of economic and social exploitation would be eliminated when the means of production were sacialized. The great experiment in Russia since 1917 shows us how much we were misled and the extent to which we were dogmatically captured...." 13 At the 1947 conference Kurt Schumacher added, "The totalitarian

12 Protokoll, 1956, p. 246.

${ }^{13}$ Protokoll, 1946, p. 104. 
bureaucrats of the communist states have the sole decision over the means of production just like the managers of the private monopoly economy of capitalism." ${ }^{14}$ Disillusionment in the Russian revolution was augmented by awareness of the threat posed by the Soviet Union. Despite the party's pronounced lack of enthusiasm for German participation in Western alliances, Schumacher's early perception of the danger was never challenged by those around him. Official statements at party conferences made it clear, for example, that while the SPD opposed German rearmament, it did not favor American withdrawal from the continent.

Observation of the communist dictatorship was of course secondary to the leaders' first-hand experience with the Nazi regime. Of the eleven paid members of the SPD executive from 1945 to 1960, five had spent part or all of the war in exile. Four had been in prison or concentration camps. The youngest of those had had military duty as well. The experiences of those around them had been much the same. Whether in exile or prison, Social Democratic functionaries had had ample time and reason to ponder the dangers of an all-powerful state. Their postwar pronouncements show the result. In 1948, a leadership spokesman said to a party conference, "The concept 'dictatorship,' no matter from whence it comes, is always suspect to us today, because we have had experiences in the last hundred years that Marx could never have had." ${ }^{15}$ At another party conference, a speaker, presenting the official economic policy statement, said: "Hitler's hubris of the omnipotent state and his pagan state-worship have caused a thoroughly healthy reaction. All state superlatives were used up and the theory of unlimited sovereignty of the state and its government today no longer finds followers. We must consider that also with regard to our socialization projects." ${ }^{16}$ In an article in the party journal, Neue Gesellschaft, an influential party expert pointed out that experience as a governing party, and with the Communists and Fascists, had made the party realize the dangers and problems inherent in a huge state bureaucracy. It was not only private economic power that should be feared; the power of economic bureaucracy when joined to the state bureaucracy was too great. Therefore public controls and distribution of economic power were preferable to socialization: "A free order demands variety in every respect. Its decisive criteria are therefore pluralism, decentralization, autonomy." 17

Study of other Western countries, both in exile during the war and after the war, also played a demonstrable part in the thinking of the leadership and its experts. At the party conference mentioned above, the economic Referent continued, "Experience in England, Sweden, and Denmark should incite us to reflection and discussion and prevent us from letting ourselves be forced into a rigid and inflexible way of thinking." 18

Many party leaders were obviously impressed by economic and social developments in the United States. In an article in the party newspaper Neuer Vorwärts,

\footnotetext{
${ }^{14}$ Protokoll, 1947, p. 51.

${ }^{15}$ Protokoll, 1948 , p. 141.

18 Protokoll, 1947, p. 162.

"Heinrich Deist, "Gemeineigentum in der freiheitlichen geordneten Wirtschaft," Neue Gesellschaft, 6 (September-October, 1959), 356.

${ }^{18}$ Protokoll, 1947, p. 164.
} 
a veteran of the prewar executive wrote: "The worker in America who five times a week drives in his own car to work for seven hours, and who returns to his own comfortable home and takes his sumptuous meal from the refrigerator, who can inform himself by radio and the newspaper, who as a free citizen takes part in the business of state, and who on every street corner can criticize his government as loudly as he wants - such a worker has really only a very distant similarity to the galley slave of the classic period." 19 A review of Vorwärts reveals many similar articles showing a continuing awareness of developments in Western countries.

Many statements indicate that the traditional concept of socialization, i.e., transfer of industry to state ownership, was being reappraised in the light of experience elsewhere. The efforts of the Labour party government in Britain were watched with special interest. In a book which was published by the Social Democratic Party in 1953, one of the party's economic experts wrote: "The experience of socialization in other countries, especially in England, has shown that the change of property relationships alone does not suffice to raise the social position of the worker and to improve relations between labor and the enterprises. ${ }^{20}$ At the 1958 conference, the leading economic spokesmen said: "We should not give ourselves up to the illusion that through transfer into public ownership the problem of dependence and bondage of the worker in the factories is already solved. . . And if we ask our English comrades how the worker problem and the codetermination of the worker in the nationalized industries has worked out, then we will hear from them that this problem is not solved through nationalization alone. ${ }^{21}$

Articles in Neue Gesellschaft suggest that the problem of socialization was a particularly hard one to resolve. In one article, the author admitted that the concept had always been central to socialist thought: "Socialization was demanded especially from two points of view: first as a means for overcoming the social class division, and second, as a prerequisite for the increasing of productivity and rationality of work and of the general welfare." Socialization had lost its central place, however, due in part to developments in the Soviet Union. "The old ruling and possessing classes, the large landowners and capitalists, did indeed disappear with the private forms of property on which their existence rested. However, in their place new social differences have arisen, a new social hierarchy, at whose head the beginning of a new ruling class, the class of bureaucratic technocracy, has developed...."

Meanwhile, in the West, because of separation of ownership and control, power had moved to the manager who held power by virtue of his position. This socialization alone could not cure. The West had learned "that it is also possible without radical socialization measures to control the course of the economy through minimal planning better than previously - as the English and Swedish development showed - and to reduce unemployment to a minimum as well as practically eliminate the industrial reserve army as a permanent phenomenon. . . There are even many arguments for the conception of Schumpeter that the monopolistic giant enterprises are

\footnotetext{
${ }^{10}$ Neuer Vorwaerts, August 25, 1950.

${ }^{20}$ Handbuch der Sozialdemokratischer Politik (Hannover: SPD, 1953), p. 191.

${ }^{21}$ Protokoll, 1958, p. 243.
} 
the bearers of scientific research and of technical progress." 22 Elsewhere the same author admitted that extensive socialization might actually create problems: "If we transfer all enterprises that are not in competition with each other into public property, that would be 60,70 or perhaps 80 per cent of German industry. We must see that. And I should like to know if, in today's world, we would transfer about 70 per cent of the industrial enterprises into public property." Political realism was essential. "We are fighting for power: We want after all to be in a position to carry out what we propose!" 23

As a result of the realization that socialization had its limitations, there was great concern with alternatives: regulatory taxation, state investment, credit controls, and welfare programs. One contributor to the party journal wrote: "The practice of the socialists of Scandinavia since the 30's and English since the second world war once and for all identified the cause of socialism with the cause of full employment and the welfare state, and thereby admittedly solved the problem of insecurity of existence in modern industrial society, insofar as it can be solved at all in a national framework." 24

Thus, in a variety of ways, leading Social Democrats showed both new perceptions of existing conditions and awareness of changing conditions. As suggested in the review of the party's ideological development, some of these extended to basic Marxist concepts. Marx's ideas of class received special attention. One contributor to Neue Gesellschaft wrote, "The prophecy stated in the Erfurt Program of 1891 concerning the inevitable growth of the proletariat and the resulting expectation of an inevitable proletarian domination in the future had for a long time been contrary to facts." ${ }_{25}$ In other ways, Marx's analyses were found no longer valid. The economic Referent remarked to the 1956 conference:

It is obviously correct that the Marxist class categories do not correspond to today's society. Society is much more differentiated today. For a long time the workers have not been a monolithic proletarian mass on the lowest stage of society, although the rosy picture, as our opponents of ten paint it, is exaggerated. . . The middle classes are in motion and the millions of pensioners are a special problem. . . . The farmers have successfully resisted the supposed law of decline of small enterprise. Therefore much of what Marx said and predicted a hundred years ago may be set aside. ${ }^{20}$

Many found that the old concepts were no longer useful for analysis. One author commented that there were still "situations similar to the class struggle," but: ". . . In this century, we have experienced such gigantic displacement among the classes, such monstrous social movements, that the concept 'class,' as the designation of something permanent, has become completely useless." In addition to greater mobility, all classes had acquired similar, middle-class desires; the bourgeoisie could

\footnotetext{
${ }^{22}$ Deist, op. cit., pp. 337-40. The reference to Schumpeter is to Joseph A. Schumpeter, Capitalism, Socialism, and Democracy (New York: Harper, 1947). In an interview, Karl Schiller stated that Schumpeter's book had greatly influenced those concerned with the economic aspect of the SPD's program development.

${ }^{23}$ Protokoll, 1958, p. 244.

${ }^{24}$ Richard Loewenthal, "Sozialismus ohne Utopie," Neue Gesellschaft, 1 (September-October 1954), 50 .

${ }^{25}$ Gustav Heinemann, "Der Weg der Sozialdemokratie," Neue Gesellschaft, 1 (SeptemberOctober 1954), 46.

${ }^{26}$ Protokoll, 1956, p. 153.
} 
no longer be identified. Moreover, labor and management could no longer be considered the "exploited" and the "exploiters": "The power of the unions today is much too great, their position too well based, for the group which they represent to be called "suppressed." These changes, the author said, called not only for new concepts and terminology, but also a new approach to the public, e.g., through the press.

We gave the newspapers the old names; we made them in the old, somewhat dry and tough style, and completely overlooked the fact that we no longer had the old reader before us, but instead, a man who is more anxious and harrassed, and who, because of radio, films, and television, no longer has the patience to read long articles, who wants to inform himself quickly, and if possible from more than one point of view. . . How much has the failure to appreciate the style of the times cost us in readers, and therefore, probably, in votes!

\section{Concerning the party program:}

What the voter wants today from a party is, in my opinion, much less fundamental. . . Public life has become so opaque and complicated; the scope of problems is so large. Who could draw any conclusions concerning the effect of any election promise, especially when all promise similar things? More and more, therefore, the voter takes another path. We can observe that in almost all the recent elections. The voter decides for the man in whom he has confidence. Usually that is someone he already knows, most of ten someone who was already successful in previous elections. That, too, is a typical feature of our time. If the SPD aspires to the government, which we all hope, it should look in its ranks for successful people. . . The drafting of resolutions belongs to the old practices of our party which, in my opinion, are not effective any more. . . These protests are not very effective outside the party. It is much more effective, on the other hand, when a known personality takes a stand.$^{. T}$

Party leaders were of course aware that other European socialist parties were in the process of reworking their programs. Erich Ollenhauer said to the Bad Godesberg conference:

It was already mentioned in the welcoming address that our program discussions occur in the midst of a series of similar program conferences in the circle of European socialist parties. It is an interesting observation that a whole serics of parties have undertaken consideration of new basic programs at the same time. The fact is worth noting that, in the program debates of all parties, there were, or are, essentially the same main problems. Our Austrian party adopted its new basic program in May of last year. The Swiss party followed it a few months ago, and as was said today, at the same time that we meet here, the Dutch workers' party discusses and adopts its new program.

Obviously, every one of these parties had to determine its position according to the social and general political conditions in its country, but, as was said in the debate, it is essentially a matter of the same problems.

We, as the German social democracy, have profited in our considerations from these programmatic discussions in important parts of the European socialist movements ....

Ollenhauer then pointed out that the party had not only observed the work of other socialist parties, but had been influenced by discussion in the Socialist International which had produced a reform program as early as 1951: "Whoever reads the [Godesberg] draft carefully will find in the whole outline of this draft and in the basic conceptions that we have developed, an extensive agreement with the Declaration of the International in which, at that time, all democratic socialist parties united after the terrible experiences of the second world war, and which thereby became the programmatic basis of international cooperation in the Socialist International." ${ }^{28}$

\footnotetext{
${ }^{27}$ Ilse Elsen, "Ist die SPD Langweilig?" Neue Gesellschaft, 6 (September-October 1959), $136-37$.

Protokoll, 1959, pp. 50-51.
} 
It is impossible to say to what extent the new perceptions described above represented the true thinking of the SPD's opinion-leaders. As might have been predicted, political rivals of the SPD attributed the party's changing views to an opportunistic quest for votes. This charge can not be dismissed out of hand. There is ample evidence that the leadership was acutely aware of its continued electoral losses. In 1958, for example, the economic spokesman told the party conference: "Comrades! The problem before which we stand and which we cannot evade after two elections, 1953 and 1957, is this: we must find methods, an attitude, and a language with which we can succeed in winning over at least 50 per cent of the people. We must think of that every minute. If we don't think of that, all other fine thoughts will have lost their meaning." 29

The extent to which the desire to win elections affected the "fine thoughts" themselves, is a matter of speculation. However, it is clear that the direction of the postwar ideological development was clearly established in the Aktionsprogramm adopted in 1952, a year before the party's first serious defeat. It seems likely, therefore, that the development was due in large part to the reaction of the party leadership to external stimuli: the outcome of the Russian revolution, the Nazi dictatorship, the experiences of Western countries, and, above all, changing conditions in postwar Germany. ${ }^{30}$

\section{The Conservatism of Power}

What of Michels' rule that "power is always conservative"? Is the Bad Godesberg Program final proof that "the struggle for great principles" is inevitably abandoned? Gertainly nothing in the program calls for drastic change. Nothing suggests that Utopia is in the offing. The program is deliberately moderate in tone and content. Given the fact that the program is the work of the party leadership, in this limited sense of the word, power did prove to be "conservative." But considering the SPD's time-honored resort to pseudo-revolutionary statements as a means of "solving" traditionalist-reformist splits, the adoption of a frankly reformist, nondoctrinaire program was a progressive, even radical step. Active, daring leadership was required to overcome intraparty resistance to the development of the new program. This leadership was supplied not by Young Turks but by men and women of years of experience in party organization and public office. In the end the program was accepted by an overwhelming majority of the active membership of the party. In this important sense, the leadership and the party were anything but "conservative."

In the light of the postwar experience of the SPD, Michels' rule that "power is always conservative" must be qualified in one respect. The conservatism of power

${ }^{29}$ Protokoll, 1958, pp. 250-251

${ }^{30}$ Unlike the SPD before World War I or the Labour party after World War II, the German labor unions had no direct influence on the postwar development of social democratic ideology. The unions are now formally independent of the party. In practice, the relationship is much like that of American labor to the Democratic party. While most of German labor is in the social democratic camp, the unions and federations aid the party only indirectly. During the period studied, the largest of the federations, the Deutsche Gewerkschaftsbund, revised its own program, no doubt reacting to some of the same factors which motivated the party leadership. While SPD leaders were of course aware of this development, as they were aware of developments in the other European socialist parties, there seems to be no substantial connection between the two. $\because x-\cdots+$ in: 
must be understood as the tendency of an elite to retain its power; it does not preclude adaptation and innovation. That is, those in power act in such a way as to conserve their power. Specifically, the leadership of a mass party which observes the forms of intraparty democracy will use all the psychological and technical perquisites of office to insure its continuance in office. To be sure, the leadership will refrain from innovation drastic enough to cause the loss of support of the active party membership to whom it is ultimately responsible. Where the membership, for whatever reason, is adamantly opposed to change, no change will occur. The democratic forms do work to this extent. But within the limits established by the preferences of the active membership, the leadership may effect change. For in order for the leadership to maintain its own position, it must also take care to maintain or improve the position of the party vis-à-vis competing parties. If the leadership, from the vantage point of superior knowledge and experience, becomes aware that changes are under way in the context within which the party functions - changes which will operate to the disadvantage of its party and to the advantage of others - it will use its influence and skill to bring about appropriate adjustments in the party's organization, program, and/or practice. This will occur even at the risk of incurring the momentary displeasure of the active membership. Failure to bring about the necessary changes, or to do so adequately, will result in a decline of the party and the ascendancy of new leaders whom the active membership believes capable of restoring the party's position.

In light of the above, it is clear that intraparty politics can not be fully understood with reference to theories which deal only with intraparty matters. This is as true of those which deal only with the function of leadership as those concerned with party structure. Intraparty politics can only be understood with reference to the whole economic, social and political context within which the party operates. This is the contribution of the contemporary political sociologists. ${ }^{31}$

\footnotetext{
${ }^{31}$ For a discussion of the changing nature of Western European society which underlies the "end of ideology," see Seymour Martin Lipset's excellent article, "The Changing Glass Structure and Contemporary European Politics," Daedalus (Winter 1964), and the works cited in his extensive bibliography. Of these, George Lichtheim's The New Europe (New York: Praeger, 1963) deserves special mention.
} 